\title{
The comparative analysis of financial performance and its effect on stock prices of banking and consumer goods companies
}

\author{
Mursidah Nurfadillah ${ }^{1}$, Ermi Utami ${ }^{2}$ \\ \{mn874@umkt.ac.id\} \\ ${ }^{1,2}$ Lecturer, Universitas Muhammadiyah Kalimantan Timur, Samarinda, 75124, INDONESIA

\begin{abstract}
This present study carried out a comparative analysis of financial performance and its effect on the stock prices of consumer goods and banking companies, both simultaneously and partially, and analyzed financial ratios that affected stock prices. The data in this research were collected through a panel data collection technique in a five-year lapse starting from 2012 to 2016. The objects of the research were consumer goods and banking companies registered on the Indonesia Stock Exchange. This research was categorized as causal research using the quantitative method and data analysis was performed using multiple linear regression. The results showed that the performance of the consumer goods companies was better than banking companies. Simultaneously, all research variables significantly influenced the stock prices of both banking and consumer goods companies with a significance value of 0,000 . Partially, the variables that influenced banking stock prices were price book value and ROE. Whereas the shares of consumer goods were significantly affected by net profit, margins, and debt to equity ratio.
\end{abstract}

Keywords: Financial performance, Stock prices, Banking, Goods companies JEL Codes: L25, A13, E49, L7

\section{Introduction}

The capital market is a meeting place or means between the demand and supply of longterm financial instruments. For the capital market issuer, this is a means to find additional capital [1] . In the capital market, the Indonesia Stock Exchange, there are multiplied large companies from the listed- sectors which generally included in the big capital company group and many investors invest their funds in these companies. The goal of all forms of investments is to earn a return, both in the form of dividends and capital gains. For this purpose, investors need to analyze and select the company that can generate the best return and the smallest risk on their investment. Investments in the form of shares (common stock) require accurate information so that investors are not trapped in adverse conditions, because investing in the stock exchange is a relatively high-risk investment, although it promises reasonably large profits [2].

There are diverse factors to consider in choosing a company in the capital market, including the company's fundamental factors. Fundamental factors are reflected in the company's financial performance, which can be seen through the level of financial ratios achieved. The better the financial performance of a company, the safer it is for investors to invest their funds. Investors are generally more interested in companies with good financial 
performance, especially for long-term investment. This will have an impact on the price of its shares in the capital market. The high interest of investors to invest in a certain company will increase its stock price [3] [4]

This present research aims to compare the financial performance of banking and consumer goods sector companies and analyze the effect of financial performance on stock prices, both simultaneously and partially, on the banking and consumer sector companies.

\section{Literature Review}

The stock price is frequently set as an indicator to measure the success of company management, where the market power in the stock market is indicated by the sale and purchase of the company's shares in the capital market. The price of a company's stock reflects the value of the company in the eyes of the public. A high price of a company's shares reflects that the company has a positive reputation in public [2].

The factors that influence the level of stock price are sorted into two; internal factor and external factor. Internal factor also referred to as a fundamental factor, is a factor that originates within the company and can be controlled by company management. This internal factor is associated with the income that will be obtained by investors in the form of dividends and capital gains. The external factor is a non-fundamental factor that is usually macro, such as legal and political conditions, inflation, changes in currency exchange rates, and fluctuations in bank interest rates.

The fundamental factor that becomes the benchmark is the company's financial condition, which is defined as the company's performance. It can be seen from the company's financial statements by comparing the level of financial ratios achieved. Financial performance as the recognition of income and the matching of costs produces higher-level profit figures to cash flow to evaluate financial performance. Income recognition ensures that all income is generated in a given period. The matching of cost validates that expenses recorded in a period are only expenses related to that period [5].

In this stduy, the researchers used several ratios of financial performance measures which can be a consideration of investors in choosing a company for investment [6]. These ratios include debt to equity ratio which reflects the ability of the company to fulfill all financial obligations or corporate debt and net profit margin which measures the company's ability to generate profits at the level of sales achieved.

The valuation of a price is reflected by the price book value and price earning ratio. Price book value is a value that can be used to compare whether a stock is more expensive or cheaper compared to other shares. The price earning ratio is a measure of the cheap or expensive of a stock when compared to other stock prices in the same industry [7].

Meanwhile, profitability is measured through the level of return on assets (ROA) and return on equity (ROE). Return on assets (ROA) measures the company's ability to generate net income based on certain asset levels [8]. The higher the level of return on assets ratio, the greater the level of profits generated by the company. In addition to ROA, return on equity (ROE) can also be used to measure financial performance. [9] highlighted that return on equity (ROE) is a ratio used to measure the net profit generated from managing capital invested by company owners. ROE is measured by comparing net income with shareholders' equity. A high ROE indicates a high return on the investment. 
Empirically there have been several researchers who investigated the problems related to macro and microeconomic conditions affecting the stock. [10] conducted research in this field by taking some research variables such as earning per share (EPS), price earning ratio (PER), return on equity (ROE), and debt to equity ratio (DER). The results showed that EPS and PER had a significant effect on stock prices, while ROE and DER had no significant effect on stock prices on the Indonesia Stock Exchange. Involved earning current ratio (CR), earning per share (EPS), price earning ratio (PER), return on equity (ROE), debt to equity ratio (DER), and total asset turn over (TATO) as financial performance variables affecting stock prices. The results of her research showed that the EPS and PER influenced stock prices significantly, while the CR, ROE, DER, and TATO had no significant effect on stock prices.

The present research focused on banking and consumer goods companies listed on the Indonesia Stock Exchange (IDX). Those types of companies were selected for several reasons. The banking sector plays an important role in the Indonesian economy since it is a financial institution that collects and distributes public funds. The consumer goods sector is a parameter of a country's industrial development. So that these two sectors are of particular concern to a country, and are relevant to be the objects of research. Thus, the submission of hypotheses in this study is detailed as follows:

H1: The financial performance of consumer goods companies is better than banking companies.

$\mathrm{H}$ 2: Simultaneously, financial performance has a significant effect on consumer goods and banking companies' stock prices.

H3: Partially, financial performance has a significant effect on consumer goods and banking companies' stock prices.

\section{Method}

This research designated as causal research, which incorporated the quantitative method. The research was conducted on the banking and consumer goods companies listed on the Indonesia Stock Exchange. It was done by analyzing the company's financial statements from 2012 to 2016. The sample of the present research was selected through purposive sampling which is included in the nonprobability sampling. In purposive sampling, the sample is selected by using certain considerations [11].

The followings are criteria used in sample selection in this present research: (1) Banking and consumer goods companies listed on the Indonesia Stock Exchange; (2) Banking companies included in the index of public companies and foreign exchange banks; (3) Consumer goods companies included in consumer goods; (4) The companies published their financial statements during the research period; and (5) The companies distributed dividends regularly From those categories, a total of 16 banks and 13 consumer goods subsector companies were obtained

The dependent variable in this research is the stock price, which is the price per common stock that occurs in a stock trading transaction on a stock exchange, which is based on the closing price at the end of the quarter, expressed in rupiah. Meanwhile, those who act as independent variables are:

1. Profit Margin

This ratio measures the level of profits that can be generated by the company from sales.

$$
\text { Profit Margin }=\frac{\text { Net income }}{\text { Net sales }} \quad x 100 \%
$$


2. Debt to Equity Ratio

This ratio compares debt to equity. The formula is as follow:

$$
D E R=\frac{\text { Total liabilities }}{\text { Equity }}
$$

3. Price Book Value (PBV)

Price book value is a comparison between market price and the book value of shares.

$$
\text { Price Book Value }(P B V)=\frac{\text { Market price per share }}{\text { Book value per share }}
$$

4. Price Earning Ratio

Price earning ratio is the ratio that compares stock prices to earnings per share

$$
\text { Price Earning Ratio }=\frac{\text { Stock price per share }}{\text { Earning per share }}
$$

5. Return on Assets (ROA)

It is a ratio that measures a company's ability to generate a profit of a certain amount of capital. This ratio is formulated as follow:

$$
R O A=\frac{\text { operating income }}{\text { Total assets }} \times 100 \%
$$

6. Return on Equity (ROE)

Return on Equity (ROE) shows the ratio between net income to equity. The following is the formula to calculate ROE:

$$
R O E=\frac{\text { Net income }}{\text { Equity }}
$$

Based on this conceptual framework, the researchers performed multiple linear regression analysis using the SPSS version 24 (Statistical Package for the Social Science) program, with a confidence level of $95 \%(\alpha=5 \%)$, and the hypothesis testing was done by using the $\mathrm{F}$ test and t-test [12].

\section{Results And Discussion}

The stock price is an illustration of investor expectations of the value of the company, the higher the stock price of a company, the greater investor confidence in the shares of the company. The banking and consumer goods stock prices can be seen in the following in Figure 1.

The bar chart shows that the average price of banking shares was far below the price of consumer goods, and the increase in annual share prices did not indicate any difference. From 2012 to 2016 the banking stock prices experienced a fluctuation of price, where the lowest price occurred in 2013 of Rp. 1,564.44, and the highest in 2016, amounting to Rp. 2,106,19. On the contrary, the price of consumer goods shares showed a stable increase from 2012 to 2015 and hit its peak in 2015 which amounted to Rp.18,567. Unfortunately, it dropped dramatically in 2016 to Rp. 6,926,3. 


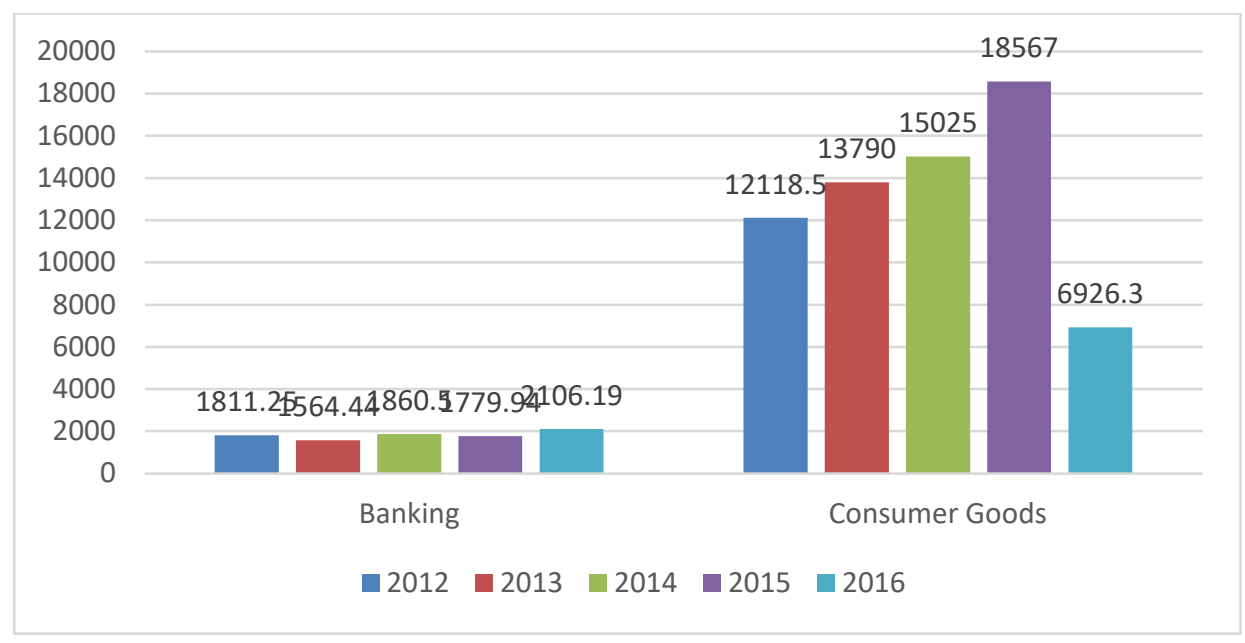

Fig.1. Stock price, 2012-2016

The NPM ratios of the banking and consumer goods companies from 2012 to 2016 can be seen in the following in Figure 2. Overall, the average net profit margin of banking companies was below that of consumer goods companies. More surprisingly, in 2016, banking NPM dropped to the negative level which was -2298.38. This happened due to one of the banking companies, BNLI, produced a very low ratio, where all the ratios achieved by the bank were negative. Meanwhile, the consumer goods companies NPM increased steadily and reached the highest point in 2016 of 3152.37 .

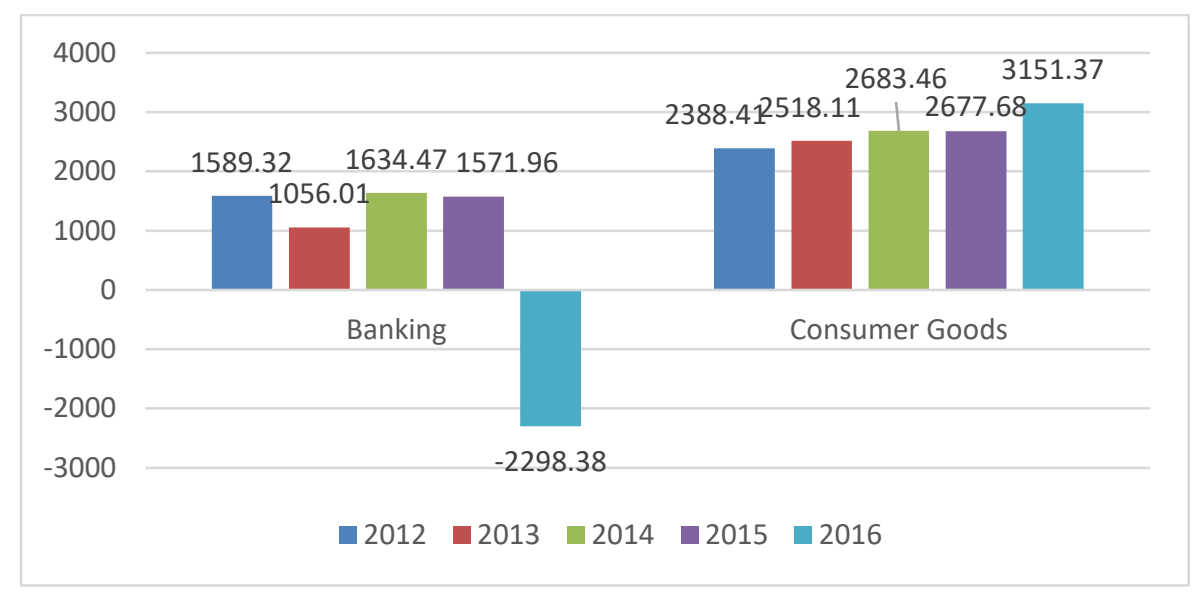

Fig.2. Net profit margin, 2012-2016

The debt to equity ratio is a comparison between debt to equity. This ratio shows the risk of the company, where the higher DER reflects the lower ability of the company to guarantee its debt with equity owned. Thus, it can indirectly affect the company's stock price and will have a negative impact on stock prices in the market. The movement of DER of banking and consumer goods companies from 2012 to 2016 is presented in the following in Figure 3. 


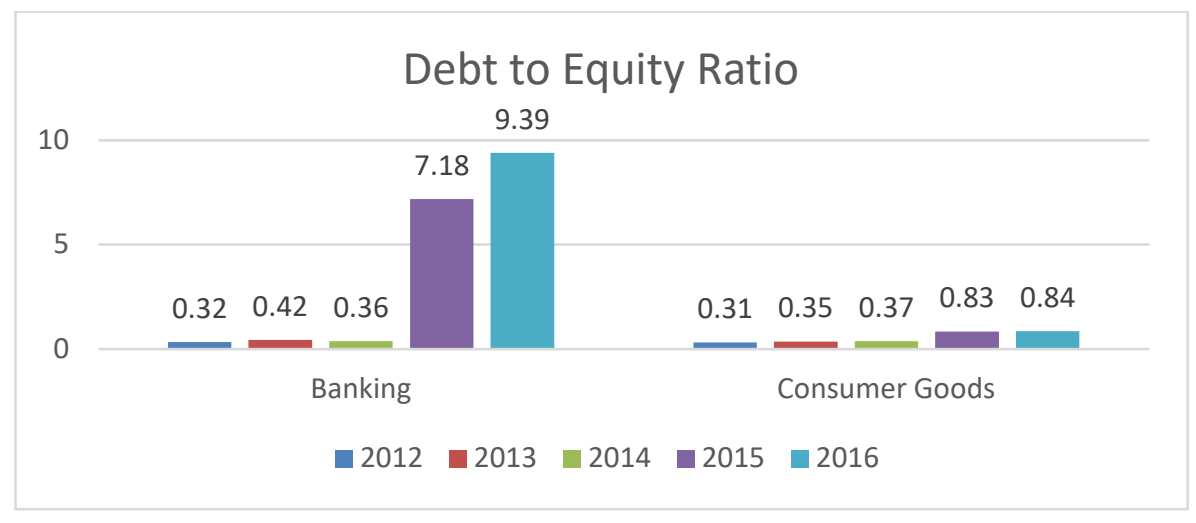

Fig.3. Debt to equity ratio, 2012-2016

The debt to equity ratio of banking companies from 2012 to 2014 was still in good condition. But in 2015 it jumped up to 7.13 and rose significantly to 9.39 in 2016 . While the DER of the consumer goods companies were still at a safe stage, where the increase in the DER level was relatively low. So, it can be concluded that the DER level achieved by consumer goods companies is better than the banking sector. The lower DER indicates the less possibility of the companies funded through debt schema.Price earning achieved by banking companies was very volatile. This could be seen from the movement of PER levels during the period 2012-2016. It arose in the period of 2012 to 2013, then declined dramatically in 2014 and increased in 2015. Finally, it dropped significantly in 2016 to a negative level. While the PER level of consumer goods companies was relatively stable, with the highest value in 2014 of 29.44 and the lowest in 2013 of 22.69 .

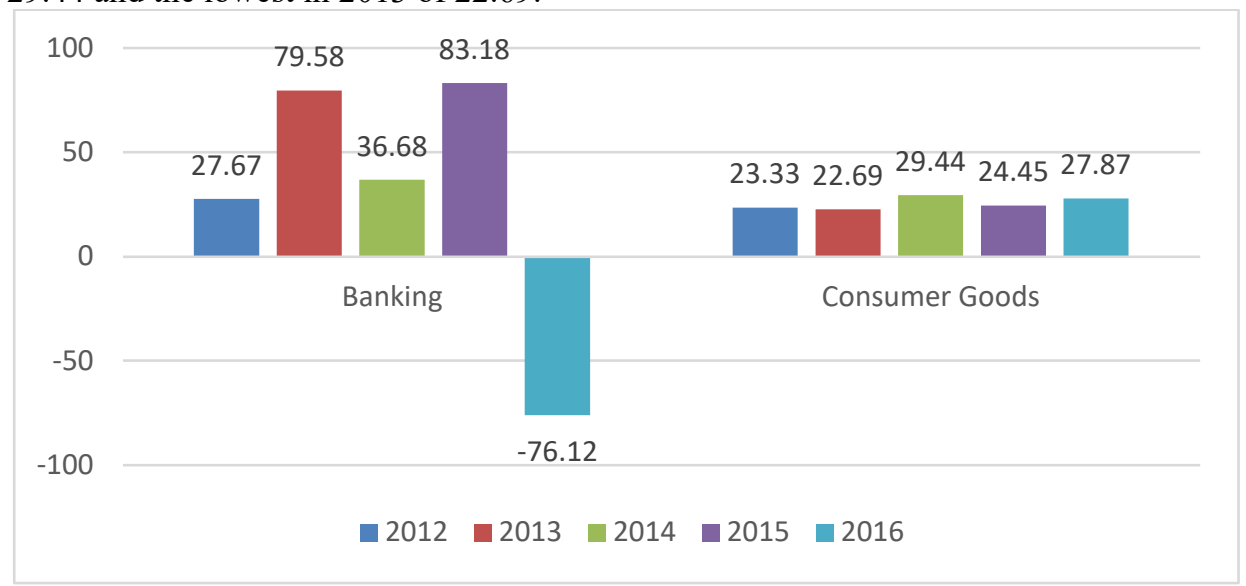

Fig.4. Price earning ratio, 2012-2016

The level of PBV achieved by banking and consumer goods companies can be seen in the following from Figure 5. 


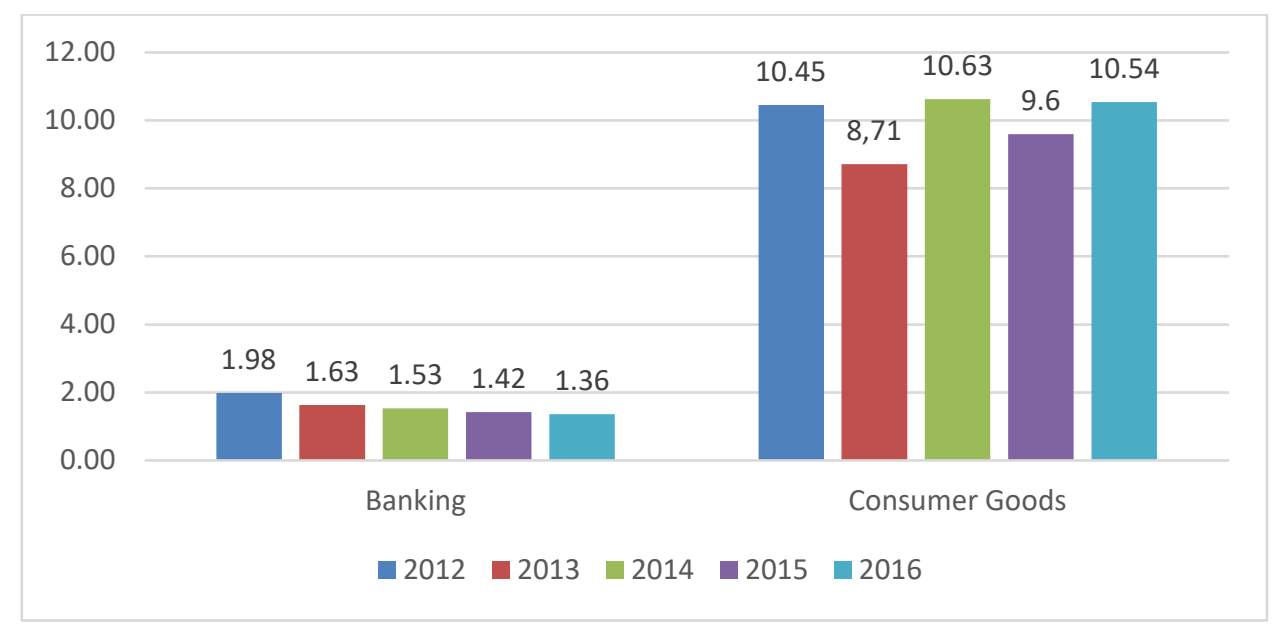

Fig.5. Price book value, 2012-2016

In Figure 5, the price book value achieved by consumer goods companies was much higher than the banking companies. From 2012 to 2016 the price book value of the bank sector had steadily declined to the lowest in 2016 of 1.36. At the same time, the consumer goods companies were relatively fluctuating, with the highest value in 2014 of 10.63 and the lowest in 2013 of 8.71 .

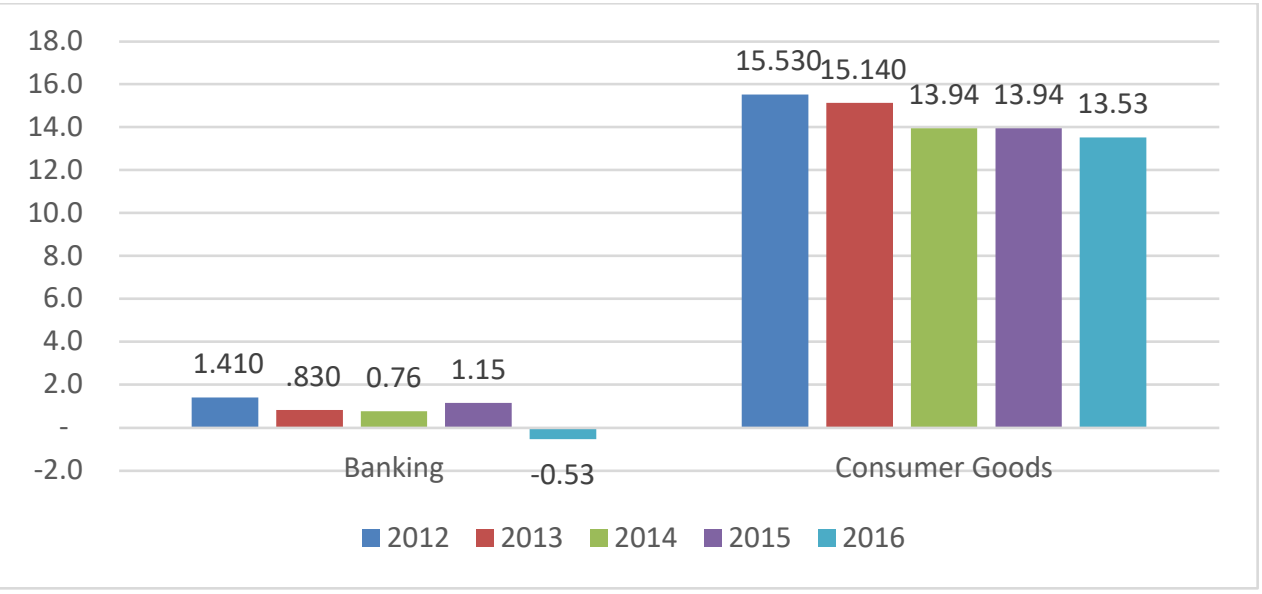

Fig.6. Returen of assets, 2012-2016

Figure 6 shows the value of return on assets (ROA) achieved by banking and consumer goods companies. In the banking company, ROA value was somewhat low and tended to decrease, the lowest number occurred in 2016, where the achieved ROA reached the negative level amounted to -0.53 . Whereas in consumer goods companies the ROA ratio was higher, with the highest rate in 2012 of 15.53 then continuing to decline to the lowest in 2016 of 13.53 . 
on equity is used to determine the efficiency of management in carrying out its capital. A higher ROE indicates a more efficient and effective use of the company's equity. This can help maintain investor confidence to invest in the company and bring a positive influence on the price of its shares in the market.

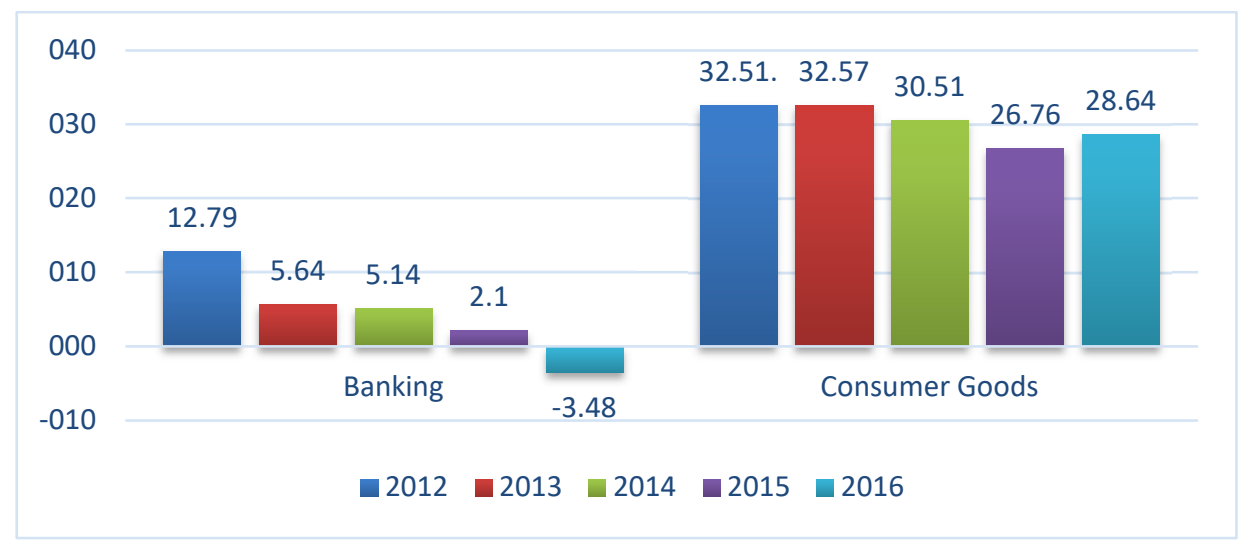

Fig.7. Return on equity, 2012-2016

Return on equity achieved by banking companies was lower than that of the consumer goods companies. The ROE of the banking companies continued to decline from 2012 to 2016 and reached the lowest point in 2016 with an ROE of -3.48. On the other hand, the ROE of the consumer goods companies was relatively higher, with the highest value in 2013 of 32.57 and the lowest in 2015 of 26.76 (see Figure 7).

Table 1: Multiple linear regression results of the banking sector

\begin{tabular}{lrrr}
\hline Variable & Coefficient & \multicolumn{1}{c}{ t-value } & Significance \\
\hline Constanta & 5.135 & 20.944 & .000 \\
NPM & $-5.697 \mathrm{E}-6$ & -.354 & .725 \\
DER & .023 & 1.380 & .172 \\
PER & $1.297 \mathrm{E}-5$ & 1.279 & .205 \\
PBV & .008 & 6.437 & .000 \\
ROA & -.033 & -.426 & .671 \\
ROE & .034 & 3.789 & .000 \\
\hline R & $=0.731$ & & \\
R & $=0.534$ & & \\
Adjusted $\mathrm{R}^{2}$ & $=0.496$ & & \\
F & $=13.936$ & & \\
Sig F & $=0.000$ & & \\
SEE & $=1.052$ & \\
\hline
\end{tabular}

Source: own tabulation 
Hypothesis testing was carried out through multiple linear regression analysis. The following highlights the results of the regression analysis with a significant level of $5 \%(\alpha=$ $5 \%$ ). Based on Table 1 and 2, the systematic multiple linear regression equations for banking and consumer goods are as follows:

$$
\begin{aligned}
& Y=5,135-5,697 X_{1}+0,023 X_{2}+1,297 X_{3}+0,008 X_{4}-0,033 X_{5}+0,034 X_{6}+\mu_{i} \\
& Y=1,561+0,737 X_{1}+0,897 X_{2}+0,032 X_{3}-0,068 X_{4}+0,001 X_{5}+0,030 X_{6}+\mu_{i}
\end{aligned}
$$

The $\mathrm{R}$ score from is 0.731 , this shows that the relationship or correlation between banking stock prices with independent variables is strong since it ranges between $0.60-0.799$ [11] While the consumer goods company has an R-value of 0.843 , which means the relationship between stocks and the independent variables is considered very strong as it extends from 0.80 -1.00 .

\begin{tabular}{lccc}
\multicolumn{4}{c}{ Table 2: Multiple linear regression results of the goods sector } \\
\hline Variable & Coefficient & t-value & Significance \\
\hline Constanta & 1.561 & 1.665 & .103 \\
NPM & .737 & 4.733 & .000 \\
DER & .897 & 2.571 & .014 \\
PER & .032 & 1.850 & .071 \\
PBV & -.068 & -1.514 & .137 \\
ROA & .001 & .014 & .989 \\
ROE & .030 & 1.350 & .184 \\
\hline R & $=0.843$ & \\
R & $=0.711$ & \\
Adjusted $\mathrm{R}^{2}$ & $=0.670$ & \\
F & $=17.596$ & \\
Sig F & $=0.000$ & \\
SEE & $=0.949$ & \\
\hline
\end{tabular}

Source: own tabulation

The measurement of the effect of independent variables on the dependent variable is shown by the coefficient of determination or the value of $\mathrm{R}$ square $\left(\mathrm{R}^{2}\right)$. Since there are more than two independent variables, the Adjusted $\mathrm{R}^{2}$ should be used instead [13]. From Table 1, it is obvious that the influence of the independent variable on the dependent variable is 0.496 . This illustrates that the effect of financial performance (NPM, DER, PER, PBV, ROA, ROE) of banking companies on their stock prices is $49.6 \%$ and the remaining $50.4 \%(100 \%-49.6 \%)$ is influenced by other variables out of research context. Table 2 shows the influence of the financial performance of consumer goods companies on their share prices is 0.670 or $67 \%$ and the remaining $33 \%(100 \%-67 \%)$ is influenced by other variables.

The standard error of the estimate (SEE) of the banking companies is 1.052, while for the consumer goods the SEE is 0.949 . The smaller SEE will enable the regression to be more precise in predicting the dependent variable.

Overall, financial performance results reflected through the ratio of net profit margin, debt to equity ratio, price earning ratio, price-book value, return on assets, and return on equity in consumer goods companies are above those of banking companies. This can be seen from the level of ratio achieved by the company. 
The results of the present research underpin that banking and consumer goods companies' financial performance consisting of net profit margin, debt to equity ratio, price earning ratio, price-book value, return on assets and return on equity simultaneously has a significant effect on the stock prices. This is indicated by the value of Fobtained which is higher than Ftable, and the level of significance of banking Fobtained $>$ Ftable $(13.396>2,225)$ and a significance level of $\mathrm{F}<5 \%(0.000<0.05)$. For consumer goods companies, $\mathrm{F}_{\text {obtained }}>\mathrm{F}_{\text {table }}(17.596>2.318)$ and a significance level of $\mathrm{F}<5 \%(0.000<0.05)$. This means that if the net profit margin, debt to equity ratio, price earning ratio, price-book value, return on assets, and return on equity change simultaneously, the stock price will also change. At this point, the level of significance of both types of companies is equal to 0.000 , which means there is a significant influence of the independent variables on the dependent variable.

This research also highlights that the variables that affect the banking stock prices are price-book value (PBV) and return on equity (ROE), while other financial performance variables used in this research have no significant effect. This shows that investors highly regard the market value of the banking shares, compared to the book value. The movement of the market value or price book value of the banking company will significantly affect the movement of stock prices in the capital market. Besides, investors also assess the performance of the banks by looking at their ability to generate income and profits based on their own working capital since banking companies are sectors that raise funds from the public and there will be the contribution of foreign capital to the company's capital. Therefore, the return on equity in banking companies is one of the main factors of investor attention, which will have a significant influence on the movement of share prices [14].

In the consumer goods company, the net profit margin and debt to equity ratio are the variables that have a significant influence on the price of the shares, and other variables do not have significant influence. This shows that investors turn to the level of profits or profits achieved by the companies since the increase in net profit margin will have an impact on the increase in income (dividends). Investors also consider the ability of consumer goods companies to pay off their obligations or debt, which is reflected through the DER ratio as the DER level will affect the security and sustainability of the invested capital. The lower the DER level achieved by the company, the safer for investors to invest their capital in the consumer goods company, and this will further influence the number of dividends they receive.

\section{Conclusion}

Financial performance, viewed from the net profit margin ratio, debt to equity ratio, price earning ratio, price-book value, return on assets and return on equity achieved, of the consumer goods companies is better than the banking companies.

The results of the analysis show that all financial performance variables namely net profit margin, debt to equity ratio, price earning ratio, price-book value, return on assets and return on equity simultaneously have a significant effect on the stock prices of the banking and consumer goods companies.

The statistical results of the t-test inform that price book value and ROE significantly influence the stock prices of banking companies. Whereas the shares of consumer goods companies are affected by profit margins and debt to equity ratio. 


\section{References}

[1] Amess, K., Banerji, S., \& Lampousis, A.: Corporate cash holdings: Causes and consequences. International Review of Financial Analysis. Vol. 42, pp. 421-433 (2015).

[2] Andarsari, F. D., Winarno, A., Istanti, L. N.: The Effect of Liquidity, Cooperative Size, And Profitability on The Capital Structure Among Koperasi Wanita In Malang, East Java. IOSR Journal of Business and Management, Vol. 18, No. 7, pp. 49-53 (2016).

[3] Azis, M., Hidayati, T., \& Adhimursandi, D.: Corporate Social Responsibility and Good Corporate Governance Toward to Equity Return in Banking: Empirical from Indonesia. International Journal of Advanced Science and Technology, Vol. 29, No. 3, pp. 9525-9531 (2020).

[4] Cai, W., Zeng, C., Lee, E., \& Ozkan, N.: Do business groups affect corporate cash holdings? Evidence from a transition economy. China Journal of Accounting Research, Vol. 9, No. 1, pp. 124 (2016).

[5] Cruz, A. F., Kimura, H., \& Sobreiro, V. A.: What Do We Know About Corporate Cash Holdings? A Systematic Analysis. Journal of Coorporate \& Finance, Vol. 30, No. 10, pp. 77-143 (2019).

[6] Darma, D. C., Maria, S., \& Pusriadi, T.: "5 Teknik Jitu" Mahasiswa Menyusun Skripsi. Kita Menulis, Medan (2020).

[7] Hanafi, M. M.: Manajemen Keuangan (Edisi 1). BPFE, Yogyakarta (2008).

[8] Hsu, W., Huang, Y., \& Lai, G.: Corporate Governance and Cash Holdings: Evidence From the U.S. Property-Liability Insurance Industry. The Journal of Risk and Insurance. Vol. 28, No. 3, pp. 715-74 (2014).

[9] Ikbal, M., Irwansyah, I., Paminto, A., Ulfah, Y., \& Darma, D. C. Explores the Specific Context of Financial Statement Fraud Based on Empirical from Indonesia. Universal Journal of Accounting and Finance, Vol. 8, No. 2, pp. 29-40 (2020).

[10] Lestari, M. I., \& Sugiharto, T.: Kinerja Bank Devisa dan Bank Non Devisa dan Faktor-Faktor yang Mempengaruhinya. Proceeding PESAT (Psikologi, Ekonomi, Sastra, Arsitek \& Sipil). 21-22 Agustus, Fakultas Ekonomi, Universitas Gunadarma (2007).

[11] Muliadi, M., Darma, D. C., \& Kasuma, J.: MSMEs as mediation in the effects of investment credit, interest rates, and labor on economic growth: Evidence from Indonesia. International Journal of Finance \& Banking Studies. Vol. 9, No. 2, pp. 1-12 (2020).

[12] Paminto, A., Ulfah, Y., Ikbal, M., Irwansyah, I., \& Darma, D. C.: Structure of Corporate Governance Important to Reduce Manipulation of Financial Statement: The Empirical Studies in the Indonesia Context. International Journal of Advanced Science and Technology. Vol. 29, No.4, pp. 5001-5013 (2020).

[13] Palazzo, B.: Cash holdings, risk, and expected returns. Journal of Financial Economics. Vol. 104, No. 1, pp. 162-185 (2012).

[14] Samsul, M.: Pasar Modal dan Manajemen Portofolio. Erlangga, Jakarta (2006).

[15] Sanjaya, A. W., \& Utiyati, S.: Pengaruh kinerja keuangan terhadap harga saham pada perusahaan otomotif. Jurnal Ilmu dan Riset Manajemen. Vol. 5, No. 9, pp. 1-16 (2016).

[16] Santoso, S.: 2005. Menguasai Statistik di Era Informasi dengan SPSS 12. Elex Media Komputindo, Jakarta (2005).

[17] Subramanyam, S., \& Wild, J. J.: Analisis Laporan Keuangan. Salemba Empat, Jakarta (2012).

[18] Sugiyono, S.: Metode Penelitian Kuantitatif Kualitatif dan R\&D. Alfabeta, Bandung (2007). 